\title{
Sunan Kalijaga dan strategi dakwah melalui Tembang Lir-Ilir
}

\author{
Yusuf Bakti Nugraha, Lutfiah Ayundasari* \\ Universitas Negeri Malang, Jl. Semarang No. 5 Malang, Jawa Timur, Indonesia \\ *Penulis korespondensi, Surel: lutfiah.fis@um.ac.id
}

Paper received: 01-04-2021; revised: 15-04-2021; accepted: 30-04-2021

\begin{abstract}
The problem that this article tries to address is about how the role of Wali Songo, especially in this discussion, is Sunan Kalijaga who uses art as a medium of preaching. In this case he used the song Lir-ilir which has a philosophical meaning in the aspect of religion. Of course this song is not just an artistic entertainment, but the message contained in this song is so deep that it is very suitable to be able to help the propagation of the spread of Islamic teachings. Even so, along with the development of the times, it is feared that this kind of culture and arts could be eroded because of the negative influences that follow from the swift currents of globalization, so that it is so difficult to maintain.
\end{abstract}

Keywords: Wali Songo; Java; dakwah

\begin{abstract}
Abstrak
Masalah yang coba dituangkan dalam artikel ini yakni tentang bagaimana peranan Wali Songo khususnya pada pembahasan ini adalah Sunan Kalijaga yang menggunakan seni untuk media dakwah. Dalam hal ini beliau menggunakan tembang Lir-ilir yang memiliki makna filosofi dalam aspek agama. Tentunya tembang ini bukan sekedar hiburan seni, melainkan memang pesan yang terkandung dalam tembang ini begitu dalam sehingga begitu cocok untuk bisa membantu dakwah penyebaran ajaran Islam. Meski begitu seiring dengan berkembangnya zaman, dikhawatirkan budaya dan kesenian seperti ini dapat tergerus karena pengaaruh negatif yang ikut dari arus globalisasi yang deras sehingga begitu sulit untuk dipertahankan.
\end{abstract}

Kata kunci: Wali Songo; Jawa; dakwah

\section{Pendahuluan}

Kedatangan Islam di Jawa memiliki pengaruh besar dalam segala aspek kehidupan bagi masyarakat Jawa yang kemudian bisa memberikan pandangan baru. Hal ini juga tidak lepas dari peran Wali Songo yang kemudian memberikan banyak pengaruh bagi masyarakat di Jawa sehingga kemudian membuat akulturasi antara kebudayaan yang ada di Jawa dengan membawa perkembangan Islam. Peran yang dimainkan oleh para Wali Songo dalam menyongsong perkembangan Islam yang kemudian dikemas dengan kebudayaan Jawa yang menarik dan bisa memikat masyarakat, membuat orang-orang di Jawa memiliki potensi lebih dalam mengembangkan Islam dengan budaya seperti yang dilakukan oleh Wali Songo.

Semangat yang kemudian diwariskan oleh masyarakat Jawa dalam membantu penyebaran Islam tentunya bernilai berharga, bahwasannya hal-hal yang kemudian dihasilkan oleh para Wali tidak menjadi sia-sia. Mengingat dalam perjalanan sejarah mengenai perkembangan Islam di Jawa yang begitu panjang karena memang keterkaitan antara Islam dan Jawa yang begitu kuat, begitu susah untuk dipisahkan. Di dalam ajaran Islam sendiri terdapat nilai yang bersifat universal dan juga bersifat absolut yang bisa mengikuti perkembangan zaman maupun dengan budaya tertentu dalam suatu daerah (Paaneah, 2019). Mengingat nilai yang terkandung di dalam ajaran Islam sebenarnya tidak kaku, karena antara suatu kebudayaan yang terdapat di suatu daerah bisa saling mempengaruhi dan memberikan 
perpaduan yang menarik. Hal ini menjadi nilai unggul karena dengan begitu Islam akan menjadi mudah untuk beradaptasi dan diterima masyarakat.

Namun juga perlu diketahui supaya tidak menimbulkan adanya kesalahpahaman, perlu diperhatikan bahwasannya meskipun agama memiliki nilai yang universal dan bisa berbaur dengan budaya, bukan berarti sesuatu di dalam agama dapat dirubah dengan seseorang, karena ajaran dalam sebuah agama merupakan keputusan yang sudah paten dan tidak bisa diubah. Bila dibandingkan dengan budaya, sebuah budaya bisa berubah dan menyesuaikan, karena memiliki sifat yang relatif, tentu bisa diberikan modifikasi daripada proses yang ada dalam sebuah budaya. Namun apabila sebuah ingin berkembang pada suatu tempat atau daerah maka diperlukan pembauran dengan sebuah budaya, bukan berarti tidak bisa berkembang apabila tidak berkolaborasi dengan budaya, karena sejatinya agama bisa terus berkembang dengan adanya hal yang bersifat paten yang ada di dalam agama itu sendiri. Tetapi jika tidak berbaur dengan budaya, agama juga berpotensi tidak memiliki tempat dalam segi kolektivitas. Perkembangan Islam di Jawa yang dibawa oleh para Wali Songo dengan membawa perpaduan kebudayaan jelas terlihat dari segi kolektivitas dan pengaruh dimata masyarakat.

Dengan membawa perpaduan kesenian dan kebudayaan yang sudah ada sejak lama di Jawa para Wali Songo berhasil memainkan peran dalam berdakwah dengan menggunakan kesenian. Strategi ini begitu berhasil untuk bisa terus mewariskan kesenian dan menggandengkan dengan tujuan persebaran Islam.

\section{Metode}

Dalam penulisan dan penyusunan artikel ini, penulis menggunakan jenis penelitian study kepustakaan (Library Research) yakni meode pencarian dan pengumpulan data dengan cara membaca cermat dan mengambil kesimpulan dari buku-buku yang ada di perpustakaan maupun jurnal online yang merupakan hasil para peneliti terdahulu, pada penulisan artikel ilmiah tersebut juga meliputi langkah-langkah untuk pengumpulan data, analisis dan juga interprestasi data daru sumber-sumper kepustakaan yang sudah penulis kumpulkan dalam tahap pengumpulan data yang sesuai dengan tema untuk penulis bahas dan kemudian di interpretasikan.

\section{Hasil dan Pembahasan}

\subsection{Sunan Kalijaga}

Salah satu tokoh dari Wali Songo yang juga memberikan andil besar terkait bagaimana perkembangan Islam di Jawa dan kemudian bisa dikatakan berhasil dalam membawa perpaduan antara seni dan agama sebagai salah satu jalan yang bisa diambil dalam penyebaran Islam, beliau bernama Raden Sahid atau biasa dikenal dengan Sunan Kalijaga. Raden Sahid dikenal dengan sebutan "maling budiman", karena pada masa Kerajaan Majapahit beliau melakukan aksi perampokan terhadap orang-orang kaya yang namun melakukan korupsi, dimana aksi yang dia lakukan adalah dengan merampok mereka ketika berada di tengah hutan dan hasilnya dibagikan kepada warga-warga yang kurang mampu. Sehingga kemudian Raden Sahid mendapatkan gelar Sunan atas perilakunya yang baik, sopan santun, dan hidupnya yang banyak membuat kebaikan seperti dalam ajaran Agama Islam (Sofwan, 2000 ). 
Sosok Sunan Kalijaga telah membawa banyak perkembangan Islam masuk ke dalam banyak kelas dan juga aspek kehidupan masyarakat. Dalam tatanan masyarakat Jawa, Sunan Kalijaga bisa membuat orang-orang dengan berbabagai kalangan dating untuk bisa belajar. Namun beliau tetap memberikan poin penting tentang Wulangan, wejangan, dan wedhangan, supaya keselarasan yang sudah dibangun sejak lama terkait jalannya budaya dan agama yang bisa beriringan menjadi hal yang susah untuk dipisahkan dan kemudian membawa pengaruh besar dalam penyebaran Islam. Pentingnya Sunan Kalijaga dalam memberikan terkait tiga pemahaman tersebut adalah mencegah supaya orang-orang yang belajar tidak salah dalam memahami dan apabila ingin memberikan suatu hal baru dari adanya keselarasan budaya dan agama, mereka tidak mengambil langkah yang salah. Karena keterkaitannya yang begitu erat, membuat orang terkadang tidak bisa membedakan antara bagaimana pemaknaan budaya dan agama secara individu. Perjalanan panjang antara budaya dan agama yang terus dijaga dan dibangun telah banyak menghasilkan adanya bentuk tradisi ataupun kearifan lokal yang memiliki nuansa perpaduan antara agama dan buaya. Hal-hal semacam ini yang memang seharusnya dijaga, karena dengan adanya kearifan lokal yang memiliki nilai keagamaan dan kebudayaan semakin memberikan pondasi kuat supaya perkembangan Islam terus berjalan harmonis dan tetap berjalan secara aman dan damai.

Dalam munculnya isu-isu di masa sekarang terkait dengan pemberian label "haram" terhadap musik, tidak jarang timbul kesalahpahaman antar sesame umat Islam. Musik yang notabene merupakan bagian dari sebuah kesenian tentu tidak bisa kita kemudian memberikan label "haram", karena sejarah dan perjalanan panjang yang telah dijalani oleh Sunan Kalijaga telah membuktikan bahwa sebuah seni yang bisa memberikan nilai keindahan juga bisa menjadi wadah untuk bisa membantu penyebaran Islam sampai diterima oleh banyak kalangan dan kemudian memeluk agama Islam pada masa Sunan Kalijaga. Sunan Kalijaga atau Raden Sahid yang membawa dakwah untuk melakukan penyebaran Islam dengan membawa kesenian merupakan pilihan yang tepat. Tentu selain musik juga terdapat seni wayang, seni gamelan, dan banyak lagi seni-seni lainnya yang bisa memberikan nilai keindahan, hiburan bahkan kenyamanan, sangat selaras bila disandingkan dengan upaya menyebarkan Islam secara damai. Karena memang apa yang dilakukan oleh Sunan Kalijaga begitu sesuai dengan kebudayaan yang ada di Jawa dan ajaran Islam bahwasannya sebagai manusia harus selalu mengutamakan kebaikan, sopan santun, dan kedamaian.

\subsection{Filosofi Tembang Lir-Ilir}

Seperti yang ada pada pembahasan sebelumnya, mengenai ketertarikan Sunan Kalijaga dalam menggunakan kesenian untuk melakukan dakwah dalam tujuan penyebaran Islam, salah satu karya yang terkenal adalah tembang khas yang menggunakan bahasa Jawa, namun juga memiliki makna penting dalam penyebaran Islam di Jawa, tembang ini berjudul Lir-ilir. Tembang ini begitu popular bagi kalangan anak-anak sampai orang-orang dewasa. Ketika tembang ini sudah banyak diketahui dan dipahami oleh banyak kalangan membuat orangorang pada umunya sering menyanyikan tembang tersebut dalam meramaikan aktivitas sehari-hari ataupun sekedar disenandungkan oleh anak-anak kecil yang sedang bermain dan berkumpul bersama. Sampai saat ini tembang ini masih tetap menjadi ciri khas Jawa, karena dengan berkembangnya zaman, tentu kesenian juga ikut merasakan dampak positifnya, maka dari itu tembang lir-ilir ini banyak di aransemen untuk dibuat lebih menarik lagi dengan bermacama-macam nada supaya nyaman di dengar dan tidak dilupakan khusunya bagi generasi muda masa kini. 
Kembali ke cerita sejarah, bahwasannya tembang Lir-ilir ini dipilih dan digunakan oleh Sunan Kalijaga untuk membantunya dalam proses dakwah Islam. Proses ini terjadi sekitar abad ke-15 di tengah perkembangan agama Hindu dan Budha yang juga begitu pesat, khususnya di Pulau Jawa (Paaneah, 2019). Langkah yang telah diambil oleh Sunan Kalijaga dalam menggunakan media dakwah dengan tembang Lir-ilir sudah tepat, sebab melihat sebelumnya agama Hindhu dan Budha yang telah lama berkembang, maka Sunan Kalijaga menggunakan tembang ini untuk bisa menyesuaikan dengan adat yang sudah berlaku sebelumnya. Strategi dakwah ini sudah sesuai dengan prinsip yang dipegang oleh para Wali Songo yang berbunyi "Kenek iwake gak buthek banyune". Yang memiliki arti menangkap ikan harus dilakukan tanpa membuat air menjadi keruh. Tentu mengenai prinsip atau filosofi yang dipegang oleh para Wali Songo ini begitu sesuai dengan kebudayaan dan bagaimana sebuah tradisi yang telah berjalan sebelumnya. Begitupun dengan apa yang sudah dilakukan oleh Sunan Kalijaga pada masa itu begitu benar menghargai adanya sebuah perbedaan dan budaya (Yaqin, 2018).

Tembang Lir-ilir ini sendiri juga memiliki makna dan filosofi yang begitu kuat sebenarnya apabila bisa benar-benar memahaminya dengan baik. Tentunya tembang ini tidak serta merta diciptakan hanya untuk kesenangan atau soal seni, tapi juga tentang arti penting yang terkandung dalam tembang ini. Tentu terdapat makna yang mendalam dalam tembang ini, dikarenakan digunakan sebagai saran dakwah oleh Sunan Kalijaga. Dalam Lir-ilir terkandung makna tentang keimanan tentang Islam seperti, rukun Islam, hal pertobatan, muhasabah (memahami diri sendiri mengenai kebaikan ataupun keburukan yang sudah pernah dilakukan), serta memperbaiki kesalahan yang telah dilakukan sebelum datangnya ajal. Setiap lirik yang terdiri dari tembang ini memiliki pesan filosofi yang dalam. Sehingga sudah sepatunya memang apabila tembang ini terus dilantunkan dan diramaikan, supaya pengajaran Islam seperti yang dilakukan oleh Sunan Kalijaga dengan menggunakan seni bisa terus berjalan dan membuat orang yang belajar menjadi mudah untuk menangkap dan memahami makna ajaran Islam.

Memang pemaknaan filosofi ini begitu luas, pemaknaan yang terkandung di dalamnya juga mengandung makna budaya. Secara struktural dan simbolis memang tembang ini begitu kuat.

\subsection{Kemajuan zaman dan minat generasi terhadap kesenian lokal nuansa Islam.}

Memang sebelum Islam masuk, ajaran dan pengaruh dari Hindu dan Budha sudah ada, yang berarti kepercayaan mereka sebelumnya adalah tentang dewa-dewa. Pada masa itu masyarakat di Jawa memang telah memiliki budaya juga kepercayaan sendiri, masyarakat Jawa telah dikenal sejak lama begitu aktif dan kaya akan tradisi. Memang tentang tradisi dan kepercayaan sebelum mengenal Islam begitu majemuk, jika dilihat dari sudut pandang masa kini tentunya membuat ada banyak kontra ataupun anggapan yang bersifat negatif tentang bagaimana tatanan kehidupan sebelum masuknya Islam. Bagaimanapun pendapat atau anggapan tentang tatanan kehidupan masyarakat Jawa sebelum masuknya Islam, harus diakui juga sudah sejak lama masyarkat Jawa hidup rukun dan berdampingan dengan adanya perbedaan. 
Dengan keselarasan dan sejalalannya antara budaya dan agama yang sudah terjalin begitu lama, tentu membuat tantangan untuk bisa menjaga dan melestarikan akan terasa cukup sulit. Mengingat perkembangan zaman yang sudah semakin maju dengan teknologi yang semakin canggih, kemudian muncul pula kebiasaan ataupun kebudayaan dari luar Indonesia yang mudah untuk masuk ke Indonesia membuat eksistensi kesenian dan kebudayaan Jawa cukup rentan untuk pudar. Warisan yang ditinggalkan sejak lama oleh para Wali Songo tentu tidak boleh kalah dengan adanya globalisasi.

Keberadaan budaya dan kesenian di Jawa harus tetap bertahan, meskipun para Wali sudah tidak ada, semangat dan warisan seni yang telah dihasilkan harus terus bertahan. Karena kekayaan budaya yang ada di Jawa begitu besar.

\section{Simpulan}

Peran penting yang dibawa oleh Wali Songo tentunya membawa dampak luas atas penyebaran ajaran Islam di Jawa, begitu banyak cara-cara yang dibawa oleh para Wali untuk bisa memberikan kesan baik sehingga penyebaran Islam bisa diterima dengan baik oleh masyarakat Jawa. Peran Sunan Kalijaga dalam menggunakan tembang Lir-ilir untuk memudahkan beliau dalam potensi untuk menyebarkan Islam. Perjalanan panjang yang ditempuh Sunan Kalijaga dalam berdakwah membawa perubahan besar bagi masyarakat Jawa. Dengan perkembangan zaman yang dibawa oleh arus globalisasi membuat eksistensi kebudayaan dan kesenian harus bisa bertahan dan tetap digemari oleh para generasi muda.

\section{Daftar Rujukan}

Putriana, S. (2020). Eksistensi Kesenian Sebagai Revitalisasi Dialog Budaya Jawa dan Islam Oleh Sunan Kalijaga. Prosiding Konferensi Ilmiah Mahasiswa Unissula (KIMU) Klaster Humanoira.

Yaqin, M. A. (2018). Dimensi spiritual tembang Lir-Ilir dalam semiotika tasawuf (Doctoral dissertation, UIN Sunan Ampel Surabaya).

Paaneah, D. Z., Sunardi, S., \& Wuryani, E. (2019). Pemahaman Syair Tembang Lir-Ilir Karya Sunan Kalijaga dalam Pembelajaran IPS pada Siswa Kelas VII B Smp Kristen Satya Wacana Salatiga. Satya Widya, 35(2), 140-147.

Sofwan, R., Wasit, H., \& Mundiri, H. (2000). Islamisasi di Jawa: Walisongo, penyebar Islam di Jawa, menurut penuturan babad. Pustaka Pelajar. 